\title{
A Comparative Study of the Buddhist Approach to Organizational Behaviour Based on the Canonical Sources
}

\author{
Padmasiri Ranawakaarachchi
}

\begin{abstract}
Organizational Behavior (OB) is one of the hot topics discussed in modern management and recognized as one of the most important factors for success of any organization. The interface between the behavior of individuals and the organization is known as the $O B$ and it is the field of study devoted to understanding, explaining and ultimately improving the attitude and behavior of individuals and groups in organizations. In this connection the researcher has developed an OB model based on contemporary management thoughts. The aim of the research is to study the concepts relating to organizational behavior and compare Buddhist approach to organizational behavior based on canonical sources. The Buddhist teaching did not much focus on presenting very complex theories on human behavior like contemporary Western scholars who have developed various theories and models to interpret human behavior. Nevertheless the Buddhist doctrine was of more practical nature which addressed all the issues of human behavior of both laymen and disciples. The existence of the order of Sangha which is considered to be the oldest democratic organization in the world for more than 2500 years shows the soundness of the organization structure and the philosophy on which it was built. When studying the monastic order and the monastic discipline in depth one could understand the management skills of the Buddha and how He had applied Buddhist teachings in managing the monastic order. Thus the Buddhist approach to Organizational Behavior is well elaborated in the Vinayapitaka. Similarly the Buddhist teaching was focused on wellbeing of the family and the behavior of individuals. Sigālovādasutta alone can be considered as one of the most significant discourses for guiding the behavior of laymen. Similarly Parābava and Mangala are a few of the many suttas addressed almost all the issues one would come across in the family. As most of the economic activities are family based, behavior of the individuals and their traits such as attitudes, values, ethics and emotions had much impact on the economy and the society at large during that period. There are many discourses in the Suttapitaka which had clearly defined ways and means to change the behavior of individuals and disciplined them with firm changes in individual traits. It is interesting to note that some of the issues addressed by the United Nations to safeguard human rights had been identified and addressed through the pañcasila and solutions for the most of the Sustainable Development Goals presented under 'the 2030 Agenda' too had been provided by the Buddha 2500 years ago. When studying the Canonical sources especially the Suttapitaka and Vinayapitaka with a view to compare the Buddhist perspective on organizational behavior against the contemporary management thoughts, it is evident that the Buddhist approach results in a permanent improvement in human behavior and the organization.
\end{abstract}

Keywords: Contemporary Management, Organizational Behavior, Individual Traits, Monastic Order, Canonical Sources 


\section{INTRODUCTION}

Today all business organizations are profit oriented. The Nobel Prize-winning economist Milton Friedman $(1970)^{1}$ once stated business' sole responsibility is "to use its resources to increase its profits." With the rapid growth in international trade and emergence of a global economy business firms operate in a challenging business environment. The business environment has dramatically changed in the recent decades. The rapid change is backed up by the rapidly expanding technology, particularly the information technology and media. These developments are so fast and the entire world is considered as a global village with no boundaries. The dynamic organizations are therefore making serious efforts to keep abreast with developments in the changing business environment while many conservative ventures are failing. Change has become inevitable. This is the essence of Buddhist thought:

"Impermanent are all component things, they arise and cease, that is their nature: They come into being and pass away; Release from them is bliss supreme." ${ }^{2}$

The Buddhist belief that nothing is permanent and referred to as impermanence, recognize that change is constant and inevitable in the environment in which we live. Therefore, all organizations are required to respond to change. The firms those respond positively achieve success by adopting to change. This is the basic challenge the business firms have addressed in their organizational behavior. The same is true where rapid changes happen consciously in the socio-economic scenario in a country. Friedman (1970) further states that the social responsibility of a business is also to 'Increase Its Profits'.

\section{Background of the Study}

With the introduction of liberalized economic policy in late 70's, Sri Lankan business environment too has changed significantly during the past four decades. Organizations have to face severe competition in the local market not only from local manufactures but from enormous imports as well. Many multinational organizations established their business in Sri Lanka and in the meantime local companies ventured into international markets.

Any organization's effectiveness over a long period depends upon the consistent development of its employees. No organization can perform effectively if Human Resource (HR) factor attached thereto is deficient.

As such, organizations are very concerned about their employees and thus human resource has become the most important resource in the organizations. In this context management in general and Human Resource Management (HRM) especially play a major role in organizational success. (Kochan \& Dyer 1992³, Idowu 20124; Ali 2013) ${ }^{5}$

\footnotetext{
1 Friedman Milton, The Social Responsibility of Business is to Increase its Profits; The New York Times Magazine, September 13, 1970. Copyright @ 1970 by The New York Times Company, Retrieved on 25 February 2016, http://www.colorado.edu/studentgroups/libertarians/issues/friedman-soc-resp-business.html

${ }_{2}^{2}$ Aniccā vata san்khārā — uppāda vaya dhammino

Uppajjitvā nirujjhanti - tesam vūpasamo sukho

Mahāparinibbāna sutta, DN.16, https://puredhamma.net, Retrieve on 25 February 2016,

3 Kochan Thomas and Dyer Lee (1992); Managing Transformational Change: The Role Of Human Resource Professionals, Paper prepared for The Ninth World Congress International Industrial Relations Association Sydney, Australia August 30 - September 3, 1992, Retrieved on 25 February 2016, http://dspace.mit.edu/bitstream/handle/1721.1/2407/SWP-3420-26847744.pdf

${ }^{4}$ Idowu Oluwatoyin Frederick (2012) Human Resource Diversity And Organizational Outcomes: Managing Differences Or Organizational Culture, Australian Journal of Business and Management Research Vol.1 No.12 [0106] | March-2012, Retrieved on 25 February 2016,
} 
However people behave differently when acting their organizational roles and the individual behavior is greatly infuenced by their culture, attitudes, emotions, values and ethics. It is also important to note that organizations are set up to achieve purposes that individuals cannot achieve on their own. The organization's base rests on management's philosophy, values, vision and goals and as a social system play a critical role too.

Hence, it is important to understand not only the behavior of individuals but how they respond to organizational requirements as well.

Chester Barnard ${ }^{6}$ recognized that individuals behave differently when acting in their organizational role than when acting separately from the organization. Organizational behavior studies the behavior of individuals primarily in their organizational roles. In doing so, organizational behavior draws most heavily on industrial and organizational psychology and social psychology. One of the main goals of organizational theorists is, according to Sims (2002), 7 "to revitalize organizational theory and develop a better conceptualization of organizational life."

Preparing managers to meet today's new challenges is of paramount importance and this can only be achieved by developing a structured approach to training and development. Another emerging issue is the knowledge worker and the quality of work life. Today education standards and aspirations of youths have gone up considerably and organizations are augmented with more knowledge workers than ever. With the exposure to multinational business environment, young employees especially executives are looking for rapid growth in their careers. Hence, organizations have a responsibility not only to provide training and development opportunities for their employees but also to provide a condusive work environment so that the employees can reach their full potential.

As a result, organizational behavior $(\mathrm{OB})$ has emerged as a critical area of management and the study of organizational behavior has become increasingly vital to the success of modern organizations.

\section{Problem Identification}

Sri Lanka has a documented history of more than 2500 years. The Great Chronicales of Ceylon, Mahavamsa (Ven. Sri Sumangala 2010) ${ }^{8}$ and Dipavamsa (Wikipedia), ${ }^{9}$ deals with the history of Ceylon from the arrival of Vijaya and his followers in the fifth centuary B.C.

A significant landmark in the history was the arrival of Arhant Mahinda, the son of the Emperor Asoka of India, a Buddhist missionary who brought Buddhism to Sri Lanka in the third centuary B.C.(Ven. Rahula 1958). ${ }^{10}$ The country had been ruled by Kings and specially during the period of Anuradhapura and Polonnaruwa massive monumental development work took place and still the ancient sites are in place to witness these achievements.

\footnotetext{
${ }^{5}$ Ali Akbar (2013); Significance Of Human Resource Management In Organizations: Linking Global Practices With Local Perspective; Researchers World -Journal of Arts, Science \& Commerce $\mathbf{E}$ E-ISSN 2229-4686 $\mathbf{\square}$ ISSN $2231-$ 4172, Retrieved on 25 February 2016, http://www.researchersworld.com/vol4/vol4 issue1_1/Paper 09.pdf

${ }^{6}$ American Business Executive and Author of many Management Books, (1886-1961)

7 Sims, R. Ronald, Organizational Success Through Human Resource management: Greenwood Publishing Group, 2002. P.12.

${ }^{8}$ Mahavamsaya (Sinhala), Buddhist Cultural Centre, Dehiwala, Sri Lanka, 07th ed. 2010.

${ }_{9}^{9}$ https://en.wikipedia.org/wiki/Dipavamsa

10 Ven Rahula Walpola, What The Buddha Thought, 9th ed., Buddhist Cultural Centre, Dehiwala.2006.
} 
With the invasion of Protugese in 1505 A. D. Ceylon had undergone tremendous changes during the next four and half centuries under Dutch and English rule. However there are mixed opinions in respect of development and their influence.

Sri Lanka having gained independence in 1948 has been subjected to immense economic and social changes under various Governments. During this period of seven decades there is no doubt that some form of development has taken place. However, it has been observed and pointed out by various parties that other countries in our region which were far behind $4-5$ decades ago have now surpassed us. In this context there is a question about the sustainability of our development which is mostly based on borrowed concepts from the west. Archeological findings too have proved that we had a well developed civilization in ancient regime of Kings most probably with much influence from the Buddhist religious background dating back to King Devanampiyatissa's time.

The Buddha was described as one of the greatest leaders and visionary of all time with an acute knowledge of human beings. In His 45 years of Buddha hood, the Buddha delivered discourses which contained many theories of management and leadership. It is also evident from the available literature that there was a well-developed administration system for Sangha. ${ }^{11}$

In Pattakammasutta, ${ }^{12}$ the Buddha discussed hierarchical form of needs, primary and secondary needs, fame, long life and emancipation, many centuries before Abraham H Maslow; American Psychologist presented a motivational theory of Maslow's Hierarchy of Needs very much in line with what the Buddha preached.

In this context the researcher believes that it is high time for us to critically study the relevance of the Buddha's teaching in contemporary management especially in the context of organizational behavior. It is also important to see whether the same is applied in our country. Being a country with over $70 \%$ Buddhists, it is of paramount importance to compare the Buddhist approach to organizational behavior with contemporary management with a view to see the possibility of applying some of the Buddhist principles in this area for the sustainable development of the country.

\section{Objectives of the Study}

Although there are many studies on the Buddhist teaching and its application in contemporary management including areas such as general management, economic management, environmental management and counseling etc., the researcher has not found a comprehensive research study covering the subject of Organizational Behavior. Therefore, the researcher attempts to study the concepts relating to organizational behavior and compare Buddhist approach to organizational behavior with organizational behavior concepts in contemporary management based on a model developed by the researcher (Figure I).

The main objectives of the research study will be as follows:

i. To study Contemporary Management concepts with special reference to Organizational Behavior

11 Sangha lit. means 'community', in Buddhism it denotes the community of 'Buddhist monks', which is the Order of Monks or Monastic Order.

12 A.4.61 
ii. To study Buddhist Management and Organizational Behavior concepts in canonical sources

iii. To compare the Buddhist approach to Organizational Behavior with Contemporary Management approach

\section{Statement of the Problems Desired to Know}

i. What are the factors that would influence organizational behavior?

ii. What are the contemporary management concepts found in canonical sources relevant to organizational behavior?

iii. What is the contribution that Buddhist concepts could make in improving the organizational behavior in Sri Lanka?

\section{Scope of the Research}

To study the management concepts applied in present organizations with special reference to organizational behavior and compare them with the Buddhist management concepts in the Pali cannon.

\section{Research Hypothesis}

As the research is a comparative study based on the available literature there are no research hypothesis.

\section{Definition of the Terms Used in the Research}

Definitions of the terms used are as follows:

i. Canonical Sources: Pali cannon consists of Tipițaka namely Sutta, Vinaya and Abidhamma.

ii. Contemporary Management: Management concepts, techniques and tools applied in managing of today's organizations.

iii. Organization: A consciously coordinated social unit composed of two or more people that functions on a relatively continuous basis to achieve a common goal or a set of goals.

iv. Organizational Behavior: A field of study that investigates the impact of individuals, groups and structure on behavior within organizations for the purpose of applying such knowledge toward improving organizational effectiveness.

\section{Significance of the Study}

With the rapid development of technology and globalization of economy, organizations have to compete intensively both in local and international markets. To be successful, organizations should not only develop products/services of superior quality but also develop its people. Therefore, it is of paramount importance to assess the behavior of individuals and the role of organizations in today's context. A research study in this area will not only enable us to understand the organizational behavior ie. the interface between human behavior and the organization and the organization itself, but also enable to critically study the Buddhist approach to organizational behavior.

\section{Research Methodology}

This is mainly a qualitative research based on the available literature and the researcher plans to apply the following methodology.

i. Reviewing Management Literature

ii. Referring to Pali cannon and reading selected suttas in the Suttapitaka

iii. Referring to selected areas in the Vinayapitaka 


\section{Advantage Expected to Obtain from the Research}

i. To gain a comprehensive understanding of Buddhist teachings in management concepts and organizational behavior

ii. To understand the Buddhist approach to organizational behavior

iii. To understand the important concepts in Buddhist teaching required for changing the behavior of people

Figure I : Organizational Behavior Model

\section{Human Behavior Organizational Culture Organizational Success}

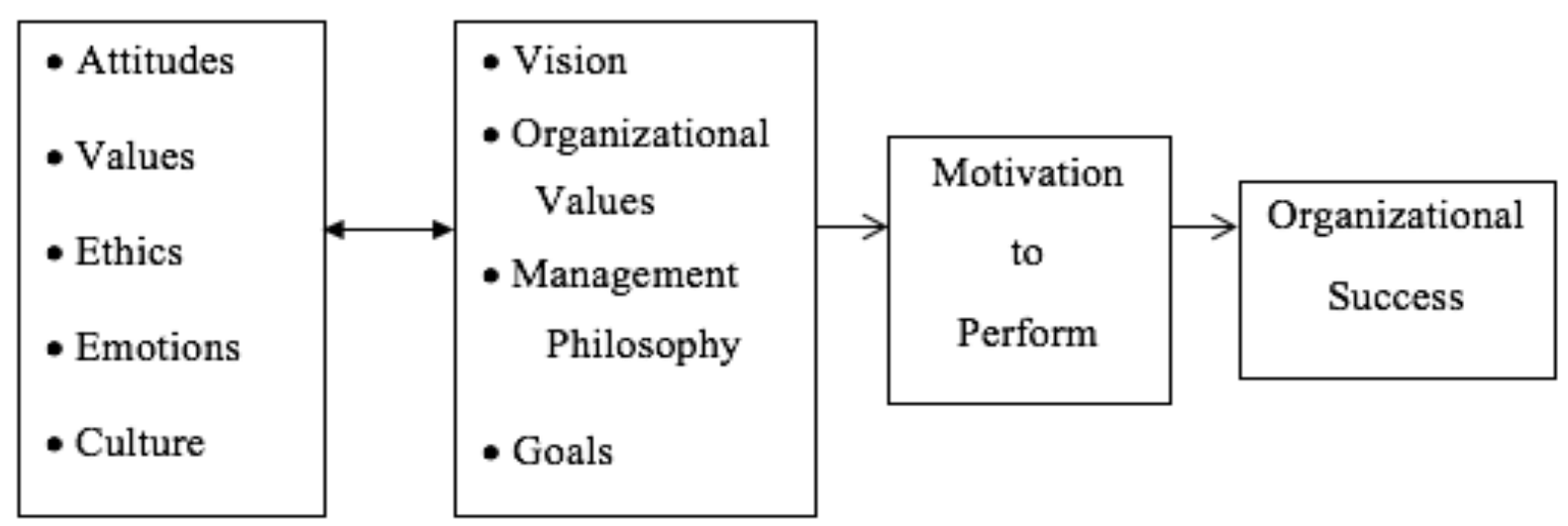

\section{MANAGEMENT AND ORGANIZATIONAL BEHAVIOR}

This following paragraphs discusses and reviews the existing literature on management, which serves as background material and basis for this study. It will focus on management, human resource management (HRM) and organizational behavior $(\mathrm{OB})$. Then it deals with the most important aspect of the research study: behavior of individuals primarily in their organizational roles.

\section{Concept of Management}

History of management dated back to a few centuries and has a relatively short history compared to other disciplines such as physics, chemistry, and economics etc. According to Moorhead and Griffin (1999), ${ }^{13}$ one of the main reasons for the relatively late development of the management as a scientific field is that a few large business organizations existed until around hundred years ago. However, there are evidences that some form of management existed from the time people started working together to perform various tasks in an organized manner. Various writers have amply corroborated this. Drucker $(1974)^{14}$ stated that:

Roots of the discipline of management goes back to one hundred and fifty years, but management as a function, management as a distinct work, management as a discipline, and area of study - these are products of this century.

A careful examination of the writing of management scholars and practitioners reveals a number of definitions of management. Management is defined as: 
"The process of working with and through individuals and groups and other resources to accomplish organizational goals (Hersey and Blenchart,1988)."15

"The process of designing and maintaining an environment in which individuals working together in groups, accomplish efficiently selected aims (Koontz and Weihrich,1988)".16

Management basically revolves around people and accomplishment of selected goals is an integral part of the process of management. Management literature offers a variety of viewpoints about the emergence of management thoughts. Academics have sought to introduce some clarity by identifying mutually supportive approaches to management.

\section{Organizational Behavior}

Practicing managers have long understood the importance of people in the organizations and interpersonal skills to managerial effectiveness. To be more precise it is the action of people which bring results and the actions of people (behavior) at work and human behavior in organizational settings and the interface with the organization is called organizational behavior (OB). It is a body of knowledge that has special implications for people at work in all types of settings and OB is the study of individuals and groups in organizations.

Luthans (2002) ${ }^{17}$ defined organizational behavior as a mixture of understanding, prediction, and management of human behavior in an organization. Further it is stated that organizational behavior represents the human side of the management, not the whole of management.

Organizational Behavior (OB) is a field of study that investigate the impact of individuals, groups and structure on behavior within organizations for the purpose of applying such knowledge toward improving organizational effectiveness (Robbins et.al, 2014). ${ }^{18}$

In summing up Organizational Behavior is the study of what people do in an organization and how their behavior affects the organization's performances. It studies three detarminants of Organizational Behavior: individuals, groups and the organization itself.

Human behavior is impacted by certain traits individual possess. These traits may vary from person to person and can produce different actions. Among many, some of the common traits are attitudes, values, ethics and emotions. Behavior is also influenced by individual's core faith and culture.

Basically organizational culture refers to a system of shared meaning held by employees that distinguishes the organization from other organizations. It creates distinctions between one organization and others. In other words it is concerned with how employees perceive the characteristics of the organization's culture. Among many, vision, values, management philosophy,and goals are recognized as the important factors that could shape and influence any organization's culture. Shared values in an organization forms its culture.

\section{Organizational Behavioral Model}

In todays' competitive and challenging environment Organizational Behavior can play a major role in organizational success enhancing overall performances of the organization through employee

\footnotetext{
15 Hersey, P., and Blanchard, K.H., Management of Organizational Behavior : Utilizing Human Resources, Prentice- Hall of India, 5th ed. 1990. p.8.

16 Koontz, H., and Weihrich, H., Management, Mc Graw Hill, 9th ed. 1988.p.4

17 Luthans. F., Organizational Behavior, McGraw Hill, Irwin, 9th ed. 2002. p. 23.

18 Robbins, S. P., Judge,T.A., Vohra,N., Organizational Behavior, Pearson Education in South Asia, New Delhi, India, $15^{\text {th }}$ ed. 2014. p. 13.
} 
motivation. In view of the literature reviewed in the preceding paragraphs a couple of input process and the outcomes have been identified in order to develop an OB model. The writer has developed the OB model considering the above facts with a view to discuss the Buddhist approach to organizational behavior and the $\mathrm{OB}$ model is depicted in figure as follows:

Figure II: Organizational Behavior Model

\section{Human Behavior Organizational Culture Organizational Success}

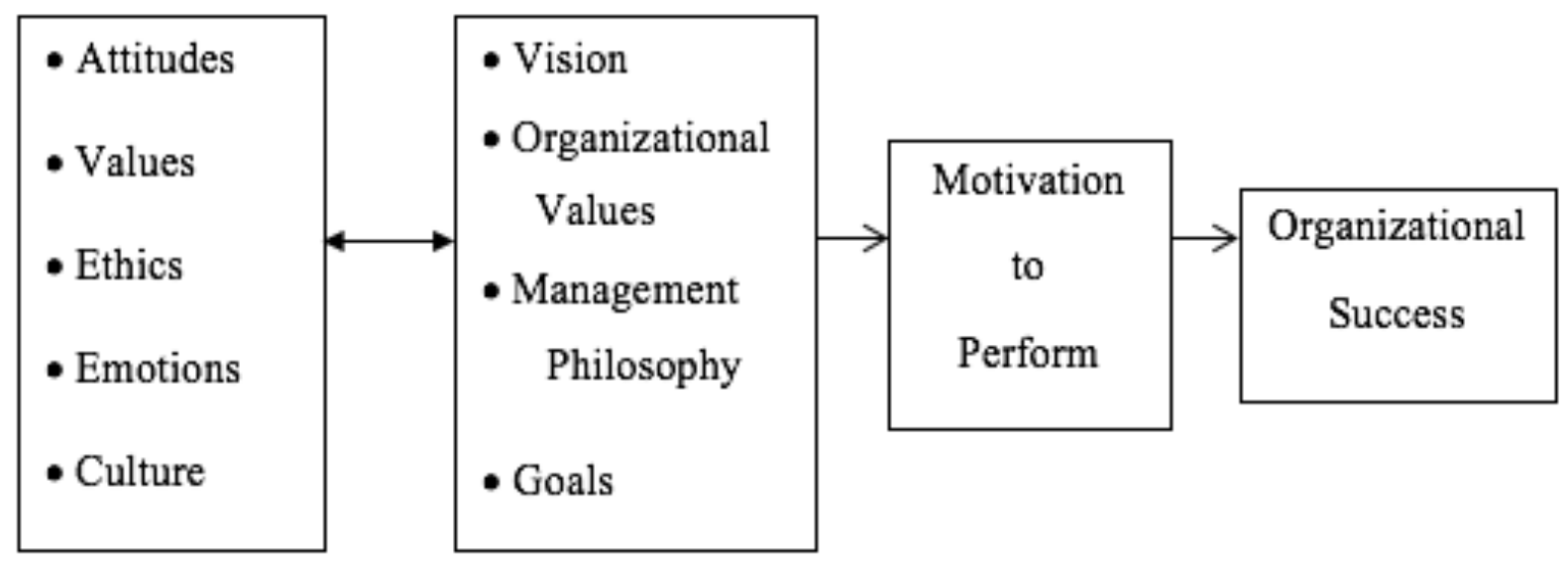

EARLY BUDDHIST CONCEPTS IN MANAGEMENT

According to the archaeological evidence, civilization appeared in India about 3000 B.C., in other words about 2500 years before the Buddha. It was at first a 'Bronze Age' civilization; roughly comparable with the civilization appeared at the same time in Mesopotamia. The history of India includes the prehistoric settlements and societies in the Indian subcontinent; the advancement of civilization from the Indus Valley Civilization to the eventual blending of the Indo-Aryan culture to form the Vedic Civilization; the rise of Hinduism, Jainism and Buddhism. ${ }^{19}$

There was a radical change of Indian religious and philosophical ideas in the $6^{\text {th }}$ century B.C., the period to which the Buddha belongs. At the time of prince Siddhärtha (the Buddha) was born, there were many religions in India with Brāhmanism was the established religion of the country. According to the Brahmajāla sutta ${ }^{20}$ there were around 62 dogmas or religious beliefs during that time. By this time the Brāhmanic religious tradition has reached its culmination. It began with the Vedas and developed through Brähmaṇas, Aranyakas and reached its climax in the period of Upanișads. Brāhmaṇas were mainly engaged in making offerings to deities and in meeting the spiritual requirements of lay life such as birth, marriages, and death etc.

The Buddha was the founder of the religion today known as Buddhism. Both in Pali and Sanskrit the term 'Buddha' means one who is awakened and the term Buddha also mean one who is enlightened. What is unique about the Buddha as a religious teacher is that unlike other religious teachers the Buddha did not claim divinity, nor attribute His knowledge to a divine source or to some kind of transcendental reality. What the Buddha preached was what He discovered through supreme human effort. Ven Rahula (2006) ${ }^{21}$ writes that:

19 https://en.m.wikipedia.org, Retrieved on 23 July 2016.

20 D. 1

${ }^{21}$ Rahula, Walpola., What The Buddha Thought, Buddhist Cultural Centre, Dehiwala, Revised Edition. 2006. p.1. 
Among the founders of religions the Buddha (if we are permitted to call him the founder of a religion in the popular sense of the term) was the only teacher who did not claim to re either God, or his be other than a human being, pure and simple. Other teachers we .reincarnations in different forms, or inspired by him

All the teachings of the Buddha can be summed up in one word: Dhamma in Pāli, in which all the Buddhist scriptures were written. Whatever the way, the Buddhism is interpreted, as a religion, a philosophy or a way of life, the most remarkable feature of the teaching of the Buddha, which was in the $6^{\text {th }}$ century B.C. is, its' similarity to modern teachings on various subjects and the relevance and applicability of the Dhamma in resolving complex problems in modern life.

The Buddha taught that to be born as a human being is a difficult and a rare achievement for one, in his sojourn through samsara. The Buddha analyzed every aspect of human life and preached the Dhamma to enable the human beings to lead a happy and a contended life and achieve the optimum advantage of being born as a human being.

The Buddha is regarded as the great visionary of all times. This is perhaps the reason for the growing interest in Buddhism, all over the world. Buddhism has unique management theory and practice developed over the years.

In fact, what the Buddha preached was relevant to modern society in every aspect and was accepted by even the westerners. In an era where there was no modern, advanced technology, this wonderful teaching is always beyond modern science. Even the advance science and technology have proved the Truth expounded by the Buddha. The Buddha's wisdom spread over a vast field of knowledge on ethics, education, law, governance, economics, management, psychology, philosophy and science. What the Buddha preached from a very complex scientific topic such as the origin of the world to simple habits like cleanliness has been accepted by academics and scholars of modern world today.

There is a striking parallel between the Buddha's approach and approach of science to the problem of knowledge. The Buddha stressed the importance of objective observation. It is the observation that yields the first of the Four Noble-Truth. ${ }^{22}$ Buddhism is noted for its analytical method in the area of philosophy and psychology.

Albert Einstein (1879-1955) US 'Theories of Relativity' stated, "if there is any religion that would cope with modern scientific needs, it would be Buddhism".

At the time of the Buddha there were many religious leaders and 62 religions in existence. The Buddha having realized the challenges ahead carefully selected the five ascetics to preach the first sermon. It was an ample proof for His visionary leadership which enabled the Dhamma to be accepted by all and be in existence for more than 2500 years.

The Buddha always addressed issues considering the macro situation and looking at the holistic picture. In that context the Buddha considered economic, environmental and social factors that would affect the human life.

Albert Einstein (1879-1955) US 'Theories of Relativity' stated, "if there is any religion that would cope with modern scientific needs, it would be Buddhism”.

22 The heart of the Buddhist teachings included in the first sermon of Dhammacakapavattanasutta 


\section{Behavior Organizational to Approach Buddhist}

The Buddha's teaching did not address the human behavior in the same manner like contemporary western scholars' who have developed various theories and models to interpret human behavior. It did not much focus on presenting very complex theories on human behavior either. Nevertheless, the Buddhist doctrine was of more practical nature which addressed all the issues of human behavior of both laymen and disciples.

The Buddha's teaching is meant not only for monks in monasteries but for the ordinary people living with their families in the society. There is a misconception that the Buddha's teaching was always for eternal life and one should give up normal life to follow it. There were many Western scholars who supported this view and popularized this misinterpretation. Max Weber was instrumental in popularizing this misinterpretation and in his book 'Religions of India',23 Weber was very critical of early Buddhism. This issue was addressed by Ven. Dr. Rahula his book 'What The Buddha Thought' and writes that;

This is a sad misconception, due to evidently to a lack of understanding of the teaching of the Buddha. People run to such hasty and wrong conclusions as a result of their hearing, or reading casually, something about Buddhism written by someone, who, as he has not understood the subject in all its aspects, gives only a partial and lopsided view of it. ${ }^{24}$

\section{Vinaya and Order Monastic}

Apart from the State or the Kingdom, always ruled by a King, Sāsana or the Monastic order is the largest organization or the institution existed during the period of 45 years of the Gautama Buddha and sometime thereafter. The Buddha is the undisputed leader of the sāsana.

Survival of the Monastic order established 2500 years ago in an era completely different to the modern World today itself vouch for the soundness of the principles and the undisputed unique leadership of the founder of it. At that time there were no big organizations except for the Kingdom where thousands of people worked. However when serving the King there was no room for compromise, but comply with whatever the role assigned to anybody. Therefore there were no specific ways of managing a large group of people under normal circumstances so that it would have been a great challenge for the Buddha to organize the monastic order.

It is evident that from the very inception some ground rules were established in recruitment and selection. One such example is that admission of non- Buddhist persons to the monastic order. Persons belonging to non- Buddhist orders could only be admitted into the monastic order after they had gone through a probationary period (parivāsa) of four months and behaved themselves properly during the admission. Persons suffering from illnesses such as leprosy, insanity and fits were debarred from admission into Sangha. Similarly persons serving the king or in royal service too were not admitted.

Vinaya or code of discipline is the set of training rules formulated by the Buddha to regulate the behavior of Sangha. Surprisingly, the Buddha introduced a code of discipline after 20 years of establishing the monastic order as no serious offence like Pārājikā or Sanghādisesa was even witnessed. It shows the standard of leadership of the Buddha and the sound organization structure of the monastic order. Although it was not in the form of discipline or the Vinaya, preaching of the Buddha always addressed righteous way of living. It is also noteworthy

${ }^{23}$ A book written by Max Weber, a German Economist published in 1916

${ }^{24}$ Rahula, Walpola., What The Buddha Thought, Buddhist Cultural Centre, Dehiwala, Revised Edition, 2006. p. 76. 
mentioning that the Buddha recited training rules or Pātimokkha as advice (ovāda pātimokkha) every fortnight to the congregation of Bhikkhu Bhikkhunīs. This was a code of discipline to be observed voluntarily. ${ }^{25}$ There was no penalty attached to the breaking of a precept.

Vinayapitaka which is known as the basket of discipline is the textual framework upon which the monastic order is built. Vinayapitaka is made up of rules of discipline laid by time to time by the Buddha for regulating the monastic order including Bhikkhu and Bhikkhunīs. These rules and procedures also support the harmonious functioning of the community as a whole. Vinayapițaka also provides many valuable lessons concerning human nature, guidance on how to establish and maintain a harmonious community and organization which are equally important for laymen as well. One important instance where the term 'Vinaya' is used for the conduct of lay people, is the reference to the famous discourse Sigālasutta as 'Gihi vinaya' or the 'Householder's discipline'.

Vinayapitaka dealt extensively of the code of discipline of both Bhikkhus and Bhikkhunis. Suttavibhanga is the first book of the Theravādin Vinayapitaka. It is a commentary on the community rules (Pätimokkha) and each rule is preceded by a story telling how the Buddha came to lay down the rule and followed by explanations. The Pātimokkha consists of two hundred and twenty seven (227) training precepts for Bhikkhus and three hundred and eleven (311) for Bhikkhunīs.

\section{Mind and Meditation}

The Buddha in his wisdom has given a position of pre-eminence to human mind. Every conscious action of individual is first conceived in the mind as thought, which is then translated into a deed by the physical body. The mind is the fore-runner in everything and whatever is conceived in mind is later put into action. According to the Buddhist teaching nature and quality of the deed depend on the degree of purity or the defilement of the mind. In simple terms purity of the mind is of significant importance to human behavior. Therefore the importance of the mind in the building of the world, in the shaping of the world cannot be overemphasised.

The ultimate spritual goal of Buddhism is the cessation of all suferings and conflicts and attain the supreme bliss of 'Nibbāna.' During that process Buddhist teaching attempts to bring about changes in the behavior of people for their own elevation and emanicipation.

Meditation or bhāvanā is the process of bringing about such changes in life style of a person. Through meditation one could change his behavior permanently and become a well disciplined person before going the full extent of achieving the final goal of 'Nibbāna.' Both physically and mentally they are disciplined.

Meditation or bhāvanā is the act of contemplation, comprehension or thinking and giving your attention to onething. Thereby one would improve his/her moral goodness and it will lead to improvement in the basic inter-personal relationship among people. This is the sort of behavior it would expect from a person in any organizational setting.

\section{RELEVANCE OF BUDDHIST TEACHING TO ORGANIZATIONAL BEHAVIOR}

The following paragraphs analyses in detail of the Buddhist teaching on management with special reference to organizational behavior as depicted in canonical sources. It compares the

\footnotetext{
25 Bhikkhuni Kusuma., Code of Conduct for Buddhist Nuns, Akana Publishers, Colombo-05, 1 ${ }^{\text {st }}$ Editionp.108.2015 ,
} 
Buddhist approach to organizational behavior based on the canonical sources with the contemporary management approach to organizational behavior.

\section{Uniqueness of Buddhism}

Before proceeding with the comparision, the writer wishes to present a few points to show the justification and validity of comparing the Buddhist teaching with modern management concepts. Early Buddhist concepts presented and discussed in the preceding paragraphs are from canonical sources of Suttapitaka and Vinayapitaka based on the teachings of the Buddha more than 25 centuries ago. As such there is no doubt about the authenticity of the materials presented for the comparision.

Early Buddhism confined only to a part of India, but today not only many countries in the region accepted it as their main religion, philosophy and a way of life, but in the western countries and the United States too. It is said that there are more than 15 million followers in America who accepted the Buddhist doctrine as a means for mental development. It is very important to see why the Buddhism has been widely accepted by people after many centuries of existence in a world where most of the modern concepts and findings get changed and become obsolete very often.

Today we live in an age of science; an age of where man is inclined to accept the truth of anything by observation and experiment rather than by mere belief. In that context the Buddhist teaching complies with the requirement of rationality much more than any other religion. In the Kālamasutta the Buddha had advised as to how one should accept anything after checking the validity and the authenticity of it and not by judging the person who said that.

\section{Comparision of Buddhist Concepts of Management}

There are ample of evidence to prove that the Buddha's wisdom spread over a vast field of knowledge on ethics, education, law, governance, economics, management, psychology, philosophy and science including the origin of the world. There is no doubt that the Buddhist teaching is relevant in today's context even after twenty five decades of its existence. On the other hand, one could argue that most of the management concepts practiced today is based on the Buddha's teaching or it was the Buddha who first presented these concepts to the world.

\section{Employee Discipline and Vinaya}

Apart from some of the common traits: attitudes, values, ethics and emotions identified in the OB model, discipline has a direct bearing on the character and behavior of any individual. As the topic of the study is centered on organizational behavior it is essential to see the influence of discipline on individual and organizational behavior. Employee discipline can be considered as the corner stone for controlling individual behavior.

The Buddhist teaching in some texts, especially in the ancient texts, are known as DhammaVinaya. English translation though it is not comprehensive, is Doctrine and Discipline. What is expected from a Buddhist layman is to observe five precepts and they are considered to be vinaya rules for layman. It is often accepted that first four precepts are more of a moral nature and accepted by every society. The fifth precept, abstinence from alcohol was not addressed in other places and given the same prominence. However by observing five precepts one can control his/her behavior and be groomed to be a disciplined person any organization or the society in general looking for.

Today organizations expect self-discipline and adopt numerous approaches to motivate employee based on financial and non-financial incentives. Still organizations can not 
completely do away with controlling the behavior of employees by disciplinary actions and imposing punishments. Situation was not much different even in the Buddhist era and that was why the Buddha had established a comprehensive disciplinary code known as 'Vinaya'. Considering the importance of the topic, entire pitaka has been devoted from the canonical sources of Tipitaka. This would vouch for the value and recognition given for individual behavior and the efforts taken to guide the behavior of disciples.

There seems to be a well-established disciplinary inquiry procedure including appointment of inquiry officer, leading evidence and hearing to both parties etc. The case of Kumara Kassapa Mātā ${ }^{26}$ decided at the time of the Buddha is an example to this process.

It is seen that many disciplinary rules establish today need to be amended, modified or completely changed at regular intervals and a few after a couple of months. It is interesting to note that all the main principles of the vinaya or code of discipline are as valid now as they were then instituted by the Buddha way back in 2500 years ago. This is indeed a marvelous proof for the superiority of the Buddhist teaching.

Today, code of discipline for controlling individual behavior addressed the aspect of positive discipline only to some extent. In fact it is quite different in the case of code of discipline for Bhikkhu and Bhikkhuniss in the monastic order. It mostly focuses on positive discipline. In a broader perspective the Buddhist approach to discipline is progressive. The objective of punishment in Buddhism is to reform the miscreant and not to resort to revenge. The principle of tooth for tooth is deprecated in Buddhism and one should extend compassion and not hatred towards even criminals.

\section{Organizational Behavior}

It is interesting to note that some of the isues addressed by International Organizations such as UN to safeguard human rights had been identified and guided the human behavior through pañcasilla etc, by the Buddha 25 centuries ago.

The United Nations (UN) announced the following seventeen Sustainable Development Goals ${ }^{27}$ (SDG) in 2015 under 'the 2030 Agenda for Sustainable Development'; No Poverty, Zero Hunger, Good Health and Well-being, Quality Education, Gender Equality, Clean Water and Sanitation, Affordable and Clean Energy, Decent Work and Economic Growth, Industry Innovation and Infrastructure, Reduced Inequalities, Sustainable Cities and Communities, Responsible Consumption and Production, Climate Action, Life Below Water, Life on Land, Peace, Justice and Strong Institutions, Partnerships for the Goals.

Former Secretary General of the UN Ban Ki-moon said, the 2030 goals 'address the requirements for all humanity to be able to live decent life free from poverty, hunger and inequality, with all men and women, girls and boys able to develop their full potential. They commit all of us to be responsible global citizens, caring for the less fortunate, as well as for our planet's ecosystems and climate action on which all life depends.'

${ }^{26}$ When other bhikkunis disparaged the bhikkuni for being pregnant and decided to disrobe her, this bhikkuni complained to the Buddha for justice. The Buddha appointed Venerable Upali to inquire into it who in turn with the whether the bhikkuni was pregnant before or after assistance of Visakha to ascertainshe entered the orderIt was . found that the bhikkuni was pregnant at the time of she entered the order, but not aware of it. Thereafter she was .or this purposeexonerated of the charge in front of the assembly summoned $\mathrm{f}$

27 https://www.un.org, Retrieve on 18 November 2018 
It is very interesting to see to what extent the Buddhist teaching had addressed the above issues. It is also surprised to note that the Budha had identified almost all and provided solutions 2500 years ago.

As mentioned above, SDGs should be considered as pre-requisites especially for any organization or the society in general. Today we live in a well developed advanced world. Entire world is considered as a 'Global Village.' Many barriers have been broken with the advancement of technology. A person can contact another within a fraction of a second and can reach anyone who lives in another part of the world within 24 hours. Then one may wonder why UN is talking about the 2030 Agenda for Sustainable Development and identified 17 SDGs. The main reason is the imbalance in development and discrimination that had taken place over the last few centuries.

In Andasutta ${ }^{28}$ the Buddha had addressed it and discussed about two fold development. The Buddha emphasised the importance of the balance between the financial developemnt and the moral development.

In Kosambiyasutta ${ }^{29}$ the Buddha said that when a person consumes wealth only by himself without sharing with others social unrest generates through jealousy and ill will which ultimately result in theft and ciminal acts. This is exactly hapenning today among countries and among people.

In the Cakkavattisīhanādasutta ${ }^{30}$ the Buddha explained further consequences of mal distribution of resources and stressed that the poverty resulted due to discrimination is the main cause for immorality and crimes.

In the Sāmañ̃naphalasutta ${ }^{31}$ and Vanaropasutta ${ }^{32}$ the Buddha emphasized the importance of protecting the environment.

It can be argued that if the development taken place had been in consistence with what the Buddha had taught there would not have been any requirement for the United Nations to come out with the 2030 Agenda for Sustainable Development.

Today organizational environment is undergoing many changes due to various reasons. Twenty First Century Organizations have to comply with new statutory requirements, demands from all stakeholders including the customers.

Traditionally businessess have assessed their performances against one bottom line; the financial aspect or the profitability. However in the last few decades many organizations moved beyond this and started to assess their performance against other factors. Organizations should incorporate concepts such as 'Triple Bottom Line' and concentrate on the Economic, Social and Environmental factors, Employees. ${ }^{33}$

Today every organization need to focus its attention on Human Rights, Sexsual Harrasement, and Corporate Social Responsibility (CSR) etc.,. The above mentioned issues were dealt in the Buddhist teaching extensively.

\footnotetext{
${ }^{28} \mathrm{~A}$

${ }^{29}$ M. 48

${ }^{30}$ D.26

${ }^{31} \mathrm{D} .2$

${ }^{32}$ S. 146

${ }^{33}$ In 1981, Freer Spreckley first articulated the Triple Bottom Line in a publication called 'Social Audit-A Management Tool for Co-operative Working'. Business writer John Elkington claimed to have coined the phrase in 1994
} 
It should be worth mentioning that the Buddhist management concepts preached by the Buddha more than 25 decades ago as presented earlier are much more in line with modern management principles and still valid. In respect of organizational behavior the Buddhist preaching gives a holistic picture. The Buddha had always considered the macro situation and addressed issues pertaining to the entire society. As such the Buddhist approach to organizational behavior is more comprehensive than the contemporary management thought.

\section{CONCLUSIONS AND SUGGESTIONS}

The present world has become more inclined towards material progress. All technological developments and advancement of science are aimed at accelerating material progress. In this context measures taken to develop people and improve human behavior has not got the attention of the authorities, nor received the equal treatment given to other areas such as economic and infrastrucuture development. It has also been noted that since there is no concerted effort all measures taken up to now is inadequate as well.

\section{Buddhist Management Concepts}

One of the most interesting points worth mentioning is that the contemporary management concepts discussed in the preceding paragraphs have been developed over the last few centuries consequent to tireless efforts and the significant contribution from thousands of academics, scholars, and practicing managers. Most of them are full time paid professionals engaged in academic and research studies with access to all modern amenities including advanced technology. In contrast most of the Buddhist concepts presented earlier were obtained from the canonical sources which were considered as the teaching of the Buddha. One should analyse or closely study how the Buddhist management concepts found in canonical sources have been developed and its acceptance by people. The salient feature is that the Buddhist management concepts has been accepted today by people in its original form even after 2500 years. It is interesting to note that various scholars especially from the Western countries and United States of America have been studying the Buddhist teaching on management in depth and proved the validity of them in todays' context. This has added more vaule to the Buddhist teaching especially to the philosopical aspect of it.

\section{Organizational Behavior}

It is also noteworthy to mention as presented above that the Buddhist perspective on organizational behavior is something beyond the organizational working enviornment. The Buddhist teaching found in canonocal sources addressed isuues not only within the organiztion and but in the external environment as well. The Buddhist teaching on economic and environmental factors has provided answers to most of the issues discussed in analysing the external environmental under concepts such as PEST (political, economic, social and technological). Out of 'tipitaka', entire vinaya pitaka has been devoted to address issues pertaining to both individual behavior and the organization. The Buddhist teaching has also provided answers to all aspects of life including the family life.

\section{Individual Behavior}

In the preceding paragraphs the modern management concepts and the Buddhist teaching on individual behavior have been discussed in detail. When compared it was evident that the Buddhist perspective is more focussed on changing the behavior of person permanently by disciplining the person and inculcating attitudanal change. This was accepted and justified by various contemporary scholars who studied canonical sources in depth. It has been proved beyond doubt that once all five senses are controlled or tamed, behaviour of individuals would be disciplined and acceptable to any environment or society. 


\section{Employee Discipline}

It is very interesting to understand the mechanism for controlling the behavior of individuals in the modern world. Although a lot of emphasis is placed on positive discipline, controlling the behaviour by punishments is not totally excluded. The malady of indiscipline afflicts all stratas of the community. In most of the organisations a code of discipline is a part of the administrative or human resouce manual. One of the salient features here is that the code of discipline is always based on a set of rules in line with the labour laws practised in the country.

Necessity for a code of discipline was first realized by the Buddha and it is important to see how comprehensive are the 'vinaya' rules promugulated by the Buddha 25 centuries ago. In establishing vinaya rules the Buddha had focused more on morality than the legal aspect of it. It has been observed that the Buddha had stressed the importance of observing sila and refered to the highest category of disciplinary rules (Päräjika sikkhäpadas) in no less than sixteen suttas of the Digha and Majjhima nikāyas. On the other hand, the Buddhist disciplinary code for lay people is also an elaboration of pañcasila. As such it is evident that sila being constitute of the norm upon which Buddhist discipline is based for both disciples and lay people.

\section{Organizational Culture}

It should be emphasized that the Buddha had on many occasions given us the necessary guidelines for the proper conduct of ourselves for achieving a state of calm and social harmony. Once this is achieved in general, working environment will be very conducive for everybody and industrial relations within the organization will be improved immensely. This will in turn result in improving the organizational behavior. Among many teachings, cultivation of the four Brahmavihāra comprising of Mettā (loving-kindness), Karunā (compassion), Muditā (sympathetic joy) and Upekkhā (equanimity) should be taken note of, understood and practiced by each one of us. It would not only enable us to improve the interface between human behavior and the organization and the organization itself, but also to mold our lives in accordance with the Buddhist teaching.

\section{Management Philosophy}

There is no doubt that the philosophy of the Buddha is of great relevance to modern thought and the modern world. Existence of the monastic order established 2500 years ago itself vouched for the soundness of the Buddhist management philosophy. It is worth mentioning that even some of the Multi-National Companies with sound management policies could not survive and wind up in the present competitive environment.

Interestingly developed countries in the west and in the east though most of them are not Buddhist countries, secret of their success is adherence to moral principles and respect for human values despite less concerned for spiritual qualities. Nevertheless scholars and learned people in the developed countries have now realized that there is a limit for such achievements and inclined for following Buddhist philosophy.

\section{SUGGESTIONS}

In rapidly changing world, it will be a challenge for the organization to maintain the equilibrium of the mindset between rapidly advancing technology and the understanding of the human cognition. As such it will be a professional imperative for employers to change and shape the attitude of the workforce in order to create a conducive mindset and values among people. This is not only a challenging task but also a difficult exercise that cannot be initiated at the organizational level. 
As discussed earlier, the Buddhist teaching had addressed the issue of changing the attitude of people at all levels. This has not only been accepted by the people in the countries of our region who are devoted Buddhists but by the intellectuals and professionals in the western and other developed countries too.

In Sri Lanka Buddhism being the religion of the majority of the citizens, Buddhist teaching can play a significant role in changing the behavior of people. As such Buddhist teaching should be taken in to consideration in conducting programs for improving soft skills of people. Initiatives should be taken at the highest level and such programs should be conducted at National level, Organizational level, and Individual level. Authorities should pay more attention on improving soft skills of childern from the begining of their carrier in education and incororate them in the school curiculam and in Dhaham Pasel (Sunday Religious Classes). 